along as his own, since it included his observations extending over very many years. The court held, firstly, that the manuscript could not belong to Hamilton College, of which Dr. Peters is Professor, nor to Litchfield Observatory, of which he is Director, but to the authors and to them alone ; and secondly, that the whole of the manuscript, numbering 3572 pages, held by Mr. Borst, had been wrongfully detained, and would have to be delivered to Dr. Peters, with compensation for the detention.

Longitude of Mount Hamilton.-A telegraphic determination of the longitude of Mount Hamilton has been made by the United States Coast and Geodetic Survey, and the result found for the transit house meridian (Fauth transit instrument) of the Lick Observatory is-

8h. $6 \mathrm{~m} .34^{\circ} 807 \mathrm{~s}$., or $12 \mathrm{I}^{\circ} 38^{\prime} 42^{\prime \prime} \cdot$ Io W. of Greenwich, with an estimated probable error \pm 0.1 . or $\mathrm{I}^{\prime \prime} \cdot 5$.

Comet Borelly, $g$ I 889 (December 12).- -The following elements and ephemeris have been computed for this comet by Drs. Zelbr and Froebe (Astr. Nach., 2943):-

$\mathrm{T}=\mathrm{x} 890$ January $27^{\circ} 743^{8}$ Berlin Mean Time.

$$
\begin{aligned}
& \pi=21 I^{\circ} 42^{\prime \prime} \text { ) } \\
& B=1659 \text { I } 7 \text {, Mean Eq. } 1889^{\circ} \mathrm{o} \text {. } \\
& \iota=595656 \\
& \log q=9.45755 \\
& \Delta \lambda \cos \beta=-4^{\prime \prime} \cdot \mathrm{I} \\
& \Delta \beta=+10 \cdot 7
\end{aligned}
$$

\begin{tabular}{|c|c|c|c|c|c|c|c|c|}
\hline \multicolumn{2}{|l|}{ r88y-go. } & \multicolumn{2}{|c|}{$\begin{array}{l}\text { R.A. } \\
\text { b. m. s. }\end{array}$} & \multicolumn{4}{|c|}{ Decl. } & $\begin{array}{l}\text { Brigh } \\
\text { ness. }\end{array}$ \\
\hline Jan. 4 & $\cdots$ & I 8 & & $\cdots$ & +2 & $36 \cdot 2$ & $\ldots$ & $3 \cdot 68$ \\
\hline 8 & $\cdots$ & & $\begin{array}{ll}35 \quad 45 \\
\end{array}$ & $\cdots$ & & 229 & $\cdots$ & 5.02 \\
\hline 12 & $\ldots$ & & $40 \quad 25$ & $\ldots$ & & 20.5 & $\ldots$ & 7.06 \\
\hline 16 & $\ldots$ & & 4640 & $\ldots$ & + & 19.7 & $\ldots$ & \\
\hline 20 & $\ldots$ & & 563 I & $\ldots$ & - & $42 \cdot I$ & $\ldots$ & 14.80 \\
\hline
\end{tabular}

The brightness at discovery has been taken as unity.

Comer Brooks, $d$ I 889 (JULy 6). - The following ephemeris is in continuation of that previously given (NATURE, vol. xli. p. II5):-

$$
1890 .
$$$$
\text { Jan. }
$$

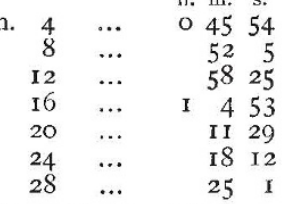

Brightness at discovery $=\mathbf{I}$.

The Sol.AR ECLIPSE. - Intelligence has been received by Mr. Turner, Secretary of the Eclipse Committee, from Mr. Taylor, stationed at Ioanda, announcing that he has obtained no observations.

\section{ACCUMULATIONS OF CAPITAL IN THE UNITED KINGDOM IN I875-85.}

$\mathrm{A}^{\mathrm{T}}$ a meeting of the Royal Statistical Society on December $\mathrm{I} 7$, Mr. Robert Giffen read a paper on accumulations of capital in the United Kingdom. He began by stating that he proposed to continue and expand the paper which he read to the Society ten years ago, on " Recent Accumulations of Capital in the United Kingdom," which dealt specially with the increase of capital between 1865 and 1875 . He would now deal with the accumulations between 1875 and 1885 , another ten years' period, and 1885 also being practically the present time, there being very little change in the income-tax assessments since 1885 , though it appeared likely enough there would be considerable changes in a year or two. His notes had extended so much, as really to become a book, which would be published immediately by Messrs. George Bell and Sons, under the title of "The Growth of Capital," and the paper he now proposed to read consisted of extracts from that book. It must be understood that the $\mathrm{c}$ )mputations were necessarily very rough and approximate only, and only designed, in the absence of better figures, to throw light on the growth of societies in wealth, and on the relations of different societies in that respect, with reference to such questions as the relative burden of taxation and national debts, the rate of saving in communities at different times, and the like. Exact figures were impossible, but approximate figures were still useful. The method he followed was to take the income-tax returns, capitalise the different descriptions of income from property there mentioned at so many years' purchase, and make an estimate for property of other kinds not coming into the income-tax returns. Formerly, in comparing 1865 and 1875 , he had capitalised at the same number of years' purchase in each year, but between 1875 and 1885 there were changes in capital value irrespective of changes in income which it was important to take notice of, at least as between different descriptions of property, though the results in the aggregate would not be much different from what they are if no change in the number of years' purchase were made. In I885, then, the total valuation of the property of the United Kingdom, according to the method followed in the paper, came to 10,000 millions sterling in round figures, equal to about $f_{270}$ per head. The principal items were: Lands, I69r millions; houses, $£ \mathrm{I}, 927,000$; railways in United Kingdom, 932 millions; miscellaneous public companies in Schedule D, 696 millions; trades and professions in Schedule D, 542 millions: farmers' profits, \&c., in Schedule B, 522 millions ; public funds (excluding home funds), 528 millions; gasworks, I 26 millions; waterworks, 65 millions; canals, docks, \&c., 7r millions ; mines and ironworks, 39 millions. These were all based on the method of capitalising income in the income-tax returns, and the principal item of other property, for which an estimate was made in a different way, was that of movable property not yielding income, e.g. furniture of houses, works of art, \&c., which was taken at about half the value of houses, or 960 millions. Comparing these figures with those of 1875 , when the valuation was 8500 millions, the apparent increase was 1500 millions, or about $17^{\frac{1}{2}}$ per cent.; but there were important changes in detail, lands having declined considerably, mines and ironworks having also declined, and there being a great increase in houses and some other items. It appeared also that the increase in the decade $1875^{-85}$ was considerably less than in the previous decade dealt with in the former paper. In $1865-75$, in fact, the increase was from about 6100 millions to 8500 millions, or no less than 2400 millions, and 40 per cent. in ten years, and 240 millions per annum ; whereas in $1875-85$ the increase was only 1500 millions, or $17 \frac{1}{2}$ per cent. in ten years, and only I 50 millions per annum. The difference in the rate of growth was ascribed very largely to a difference in the rate of growth of money values only, reasons being given for the belief that in real prosperity, in the multiplication of useful things, and not merely money values, the improvement in the later period was not less than in the first. The distribution of this great property between England, Scotland, and Ireland, could not be exactly shown, part of the income belonging to the community of the United Kingdom in a way which did not permit of a distinction being made; but upon a rough estimate it appeared that England was considered to have 8617 millions, or 86 per cent. of the total; Scotland, 973 millions, or 9.7 per cent. ; and Ireland, 447 millions, or 4.3 per cent. These figures worked out about $£ 308, £ 243$, and $£ 93$ per head respectively, as compared with the average of $£ 270$ for the United Kingdom. The small relative amount of property in Ireland was commented upon, and the difference between it and Great Britain was ascribed very largely to the political agitation in Ireland, which depreciated property, and the excess of population on the land, which had the same effect; these two causes together making a difference of 200 millions in the apparent capital of Ireland. Measured by property, Ireland was enormously over-represented in the Imperial Parliament. Looking at the subject historically, they found that there had been an enormous and continuous advance in the course of the past three centuries, during which at different times there had been contemporary estimates on the subject. In 1600 the property estimate was for England only Ioo millions, or $\$ 22$ per head; 1680,250 millions, or $£ 46$ per head; 1690,320 millions, or $£ 58$ per head; 1720,370 millions, or $£ 57$ per head; 1750,500 millions, or $£ 71$ per head; and in 1800,1500 millions, or $f \mathrm{I} 67$ per head. The estimate for Great Britain in the latter year being about one-eighth more in the aggregate than for England only, and $£ \mathrm{I} 60$ per head. Since 1800 there are figures for the United Kingdom, and these show : 1812, 2700 millions, or $£ \mathrm{I} 60$ per head; 1822,2500 millions, or $£ \mathrm{I} 20$ per head (a reduction largely due to fall of prices); I833, 3600 
millions, or $\oint_{1} 44$ per head; 1845,4000 millions, or $£_{1} \mathrm{I} 43$ per head; 1865,6000 millions, or $£ 200$ per head; $187.5,8500$ millions, or $£ 260$ per head; and finally, the present figures of ro,000 millions, or $£ 270$ per head. There was in fact a steady increase, with the exception of the interval between 1812 and 1822 , when there was a heavy fall of prices, and this increase, it was believed, represented almost all through a real increase in things, money prices at any rate being at a lower rate now than at the beginning of the century. There had also been a remarkable change all through in the proportions of different descriptions of property. Lands, at the commencement constitute about 60 per cent. of the total; at the beginning of the century they are still about 40 per cent. ; at the present time they are $\mathbf{I} 7$ per cent. only. Houses, on the o'her hand, are about $\mathrm{I}_{5}$ per cent. of the total at the beginning, and 19 per cent. at the present time, an increasing percentage of an ever increasing total ; but the main increase after all is in descriptions of property which are neither lands nor houses. After referring to the accumulations of capital in foreign countries, Mr. Giffen concluded by giving illustrations of the mode of using such figures, showing the difference of the burden of taxation and national debts in Lingland, France, and the United States; the preponderance of England in the United Kingdom as compared with England, Scotland, and Ireland; the rapid growth of the United States in recent years as compared with the United Kingdom, and especially as compared with France (the national debt in the United States, from amounting twenty years ago to a sum equal to a fifth of the total property, having come to be only equal to a thirtieth of the property); and the small proportion of the annual savings of the country which comes into the public market for investment, as compared with the savings invested privately as they are made. In passing, a reference was made to the talk of the vast expenditure on military armaments, and the burden they impose on certain communities; and it was suggested that, heavy as the burdens are, yet the vast amount of property relatively indicated that the point of exhaustion was more remote than was commonly supposed. In conclusion, the hope was expressed that the discussion of recent years would lead in time to the production of better figures, especially with regard to the growth of different descriptions of property. Were trouble taken, results might be arrived at which would be of value to the Government practically, as well as to economists in their discussions. The progress of revenue was intimately connected with the progress of national resources, and the progress of money revenue with the progress of the money expression of those resources. The resources themselves, and the money values, must be studied by Chancellors of the Exchequer with almost equal anxiety, and they should both, at any rate, be studied together. Periodical complete valuations of property were in this view as indispensable as the census of population itself.

\section{UNIVERSITY AND EDUCATIONAL INTELLIGENCE.}

University College, Liverpool. - The Sheridan Mus pratt Chemical Scholarship, of the value of $£ 50$ per annum for two years, has been awarded to Mr. J. T. Conroy, who has been a student in the chemical laboratories during the past two years. Mr. Conroy has recently taken the degree of B.Sc., with honours in chemistry, at the University of London. The Scholarship, which is the gift of Mrs. Sheridan Muspratt, is intended to enable the holder to continue work in the higher branches of chemistry. The Sheridan Muspratt Exhibition of $£ 25$ has been awarded to Mr. A. Carey, of Widnes, who has been a student of the College during the last two and a half years, and is now in the final stage of preparation in the honours school of chemistry of Victoria University.

\section{SCIENTIFIC SERIALS}

Rendiconti del Reale Istituto Lombardo, November.-On the antidotes of the virus of tetanus, and on its prophylactic surgical treatment, by Prof. G. Sormani. In continuation of his previous paper on this subject, the author here describes some further experiments with alcohol, chloroform, and various preparations of camphor, chloral, and iodine. He finds that cam phor and camphorated alcohol produce no effect on the virus, and that chloroform and hydrated chloral have a more or less attenuating action, checking the development of the artificially cultivated microbe, or even in some cases rendering it absolutely sterile, while camphorated chloral has a decidedly neutralizing effect on the virus. Other experiments show that when tetanus is once developed in the system iodoform is powerless to arrest its progress, but is most efficacious in neutralizing the virus of the injured part. The whole series of experiments fully confirms the author's previous conclusion that iodoform is the specific disinfectant of the microbe of tetanus.

Bulletin de l'Académie Royale de Beloique, October I2.Jupiter's north equatorial band, by M. F. Terby. The author describes in detail the structure of this remarkable phenomenon which he has been carefully studying for the last three years with a Grubb 8-inch telescope.-Determination of the invariani functions or forms comprising several series of variants, by M. Jacques Deruyts. In continuation of his previous communications, the author here extends to forms with several series of variants the results already made known for forms with a series of $n$ variables. - M. C. Vanlair describes the symptoms and treatment of a new case of bothriocephaly in Belgium, due to the presence of Bothriocephalus latus in the patient.

\section{SOCIETIES AND ACADEMIES.}

\section{LONDON.}

Royal Society, December 5, I889. - "Researches on the Chemistry of the Camphoric Acids." By J. E. Marsh.

An account is given of some experiments leading to the production, in any desired quantity, of a new camphoric acid, and to the mutual conversion of one acid into the other; as well as to a method of quantitatively separating the two acids when mixed. The space at our disposal does not permit us to enter into any details of the experiments, nor into the theoretical considerations involved. For this, reference must be made to the original paper.

December 19, 1889. - “ On the Steam Calorimeter." By J. Joly, M.A. Communicated by G. F. Fitzgerald, F.R.S., F.T.C.D.

The theory of the method of condensation has been previously given by the author in the Proceedings of the Royal Society, vol. $4 \mathrm{r}, \mathrm{p} .352$

Since the publication of that paper a much more extended knowledge of the capahilities of the method has been acquired, which has led to the construction of new forms of the apparatus, simple in construction and easily applied. Two of these are described and illustrated, one of which is new in principle, being a differential form of the calorimeter. The accuracy of observation attained by this latter form is so considerable that it has been found possible to estimate directly the specific heats of the gases at constant volume to a close degree of accuracy.

An error incidental to the use of the method arising from the radiation of the substance, when surrounded by steam, to the walls of the calorimeter, is inquired into. It is shown that this affects the accuracy of the result to a very small degree, and is capable of easy estimation and elimination.

Further confirmation of the accuracy of the method is afforded in a comparison of experiments made in different forms of the steam calorimeter.

Various tables of constants are given to facilitate the use of the method, and the results of experiments on the density of saturated steam at atmospheric pres-ures, made directly in the calorimeter, are included. These are concordant with the deductions of Zeuner, based on Regnault's observations on the properties of steam, and were undertaken in the hope of affording reliable data on which to calculate the displacement effect on the apparent weight of the substance transferred from air to steam.

The communication is intended to provide a full account of the mode of application of the steam calorimeter.

Royal Meteorological Society, December 18, 1889.-Dr. W. Marcet, F.R.S., President, in the chair.-The following papers were read:-Report of the Wind Force Committee on the factor of the Kew pattern Rubinson anemometer. This has been drawn up by Mr. W. H. Dines, who has made a 